\title{
The Effect of Performance, Price Perception, Brand Image, and Brand Association on Purchase Decision of Honda CBR150R in Surabaya
}

\author{
Ponta Dewa Saktiawan ${ }^{1}$ and Soni Harsono ${ }^{2}$ \\ 1,2STIE Perbanas Surabaya, Indonesia
}

\section{Article history:}

Submitted: 22 November 2020

Revised: 19 March 2021

Accepted: 25 March 2021

\section{Keywords:}

Marketing

Performance

Price perception

Brand image

Brand association

Purchase decision

Indonesia
ABSTRACT. In the automotive industry, the consumer purchase decision is the most important aspect of the company's life cycle because it can affect profitability, especially for Honda CBR 150R. This study aims to analyze the effect of performance, price perception, brand image, and brand association on the purchase decision of Honda CBR 150R in Surabaya. The research design is descriptive-correlational. Data were collected by distributing 113 questionnaires to the respondents who met the inclusion criteria. The data were analyzed using multiple regression analysis. This research shows that performance and price perception have a negative effect on purchase decisions, but not significantly. The brand image has a positive effect on the purchase decision, but not significantly. On the other hand, brand association has a positive and significant effect on a purchase decision. It can be concluded that brand association is the most important aspect in Honda CBR 150R purchase decision.

\subsection{Introduction}

Recently, competition in the motorcycle industry, especially in the $150 \mathrm{cc}$ sport fairing category, has kept companies busy developing and improving their technologies, machinery, and other motorcycles support. The rapid growth and changes in the motorcycle industry in $150 \mathrm{cc}$ are caused by the growth of the demand by the consumers. To meet consumers' demand for motorcycles, Honda presents the CBR 150R to compete with two other Japanese manufacturers. They are Yamaha YZF R15 and Suzuki GSX R150 that are motorcycle products from two Honda competitors.

There have been 38,873 units sold as the choice among 4,800 motorsport lovers every month. In 2016, Honda launched the next generation of the CBR 150R in Indonesia. The next generation, the All-New CBR 150R with the code K45G (Automotive Journalists' Forum - in Liputan 6) is the best motorcycle of the year through a Forwot Motorcycle of the Year (FMY) event. However, in the next competition, in May 2017, Yamaha was ahead of its rivals with R15 sales reaching 8,526 units, followed by the Honda CBR150R with 7,241units, then Suzuki GSX-R150 with 3,897 units. In 2017, the Honda CBR 150R again knocked out the next generation of YZF R15, named the All-New YZF R15. Suzuki also entered the market competition in the $150 \mathrm{cc}$ sport fairing bike class by presenting the GSX R150.

As of June 2018, Yamaha, with R15 sales, reached 4,893 units. Then, it was followed by the Honda CBR150R with 2,609 units, then also Suzuki GSX-R150 with 465 units. In 2018, Honda then launched the next generation of the CBR 150R from the previous generation with code $K 45 \mathrm{~N}$ to compete with Yamaha YZF R15 and GSX R150. Although Honda has updated its motorcycle technology, Yamaha YZF-R15 can still outperform Honda CBR 150R motorcycle sales. This is the second time Yamaha YZF R15 could overtake sales from Honda CBR 150R since Yamaha YZF R15 appear in 2014.

The sale decrease above was due to the company's inability to meet consumer demand in the $150 \mathrm{cc}$ sport fairing bike competition, affecting the purchasing decisions. Pratiwi (2015) suggested the companies should pay attention to modern society's different consumption parameters, evaluating and selecting the various alternatives by determining a choice with the most profitable.

Several factors are affecting the customers' purchase decision. Ashaduzzaman et al. (2018) stated that performance affects motor purchase decisions. Kotler and Keller (2009) also stated that product performance has a value that also affects purchasing decisions. The customers' purchasing decisions can be higher due to the value of the product that is based on performance. In that case, Honda CBR 150R has the lowest horsepower output from the performance point of view. As a result, CBR 150R becomes the slowest bike in 150cc. Honda equipped the CBR 150R with a $150 \mathrm{cc}$ DOHC 
engine producing the lowest power. Other proponents, Widyastuti and Said (2017), revealed that price perception also affects purchase decisions.

Widyastuti and Said (2017) also argued that brand could affect purchase decisions. This is also supported by Dib and Alnazer (2013), stating that brand image - as an association in the consumers - can affect the purchasing decision. Fattah (2016) also found that the brand image was built on consumers' minds, such as the strength of the brand association, knowledge, and assessment of a consumer for the All-New Honda CBR $150 \mathrm{R}$ as motorsport produced by Honda. The strength of this brand association is identified by the popularity and credibility of the All-New Honda CBR $150 \mathrm{R}$, comfortable and famous. All these are the best quality in its class, with high resale prices.

Other researchers, such as Yanti and Sukotjo (2016) and Aaker (1997), argued that brand association affects purchase decisions. Brand as they described can be formed through the combination of attitudes, attributes, and benefits. The impressions that arise in the consumers' minds are the factors such as communication, the marketing of a brand, their experience, and the consumption of the brand by other people. The relationship with the product increases together by increasing the number of customer experiences in purchasing a brand or by increasing the brand's presence in the communication strategy of the companies.

On the one hand, it appears that Honda CBR-150R has been in very tight competition with other motorbikes. However, Honda CBR-150R is considered to have the opportunity to overtake other competitors by increasing the customers' purchasing decision. For that reason, as referring to the previous studies, the researchers assume that there are some factors affecting the consumers' purchasing decision to buy motorbikes of Honda CBR 150R. These factors are performance, price perception, brand image, and brand association. This research, therefore, attempts to investigate the effects of these factors on the customers' purchasing decision so that Honda CBR-150R can design strategies to increase the customers' purchasing decision.

\subsection{Framework of the Study}

\section{Performance}

Performance is a motorbike product attribute, e.g., the sport firing, is an important factor for a motorbike. Based on the Focus Group Discussion (FGD) by Ashaduzzaman et al. (2018), performance is mostly used by the customers for deciding to purchase a motorbike. This is also supported by a research result of Puspitasari (2013) that the motor engine performance affects the customers' decision to buy motorbikes. The performance includes torque, power, and specific fuel consumption. Likewise, Kotler (2010) strongly also argued that performance has a functional aspect, as the main characteristic of motorbike and affects purchasing decision.

Other proponents-Fink et al. (2011), also provide the same evidence. They found that the performance of certain products can affect the customers to buy the products. In this case, Ashaduzzaman et al. (2018) suggest that manufacturers better develop their new products for increasing performance. There are some important criteria for buying a car, but one of them is car performance (Aghdaie \& Yousefi, 2011). The performance indicators are engine, quality, millage of the engine, and engine power (Ashaduzzaman et al., 2018).

\section{Price Perception}

Price perception is another important factor affecting the customers' purchasing decisions. Widyastuti and Said (2017) provide evidence that the price is primarily considered by the customers before deciding to buy any products or services. They argued that price is used to consider buying the products or services. In the perspective of marketing, a price is a monetary unit or another measurement. Price refers to money as a means of exchange for products or services. Price, as they described, should also be flexible. Therefore, price is identical to money with its ability to provide the customers with product possession. They have to use it to buy any product they want to.

Price can change and adapt to the market dynamics. Price is viewed from the perspective of price competition, for example, in a discount war. Dib and Alnazer (2013) stated that consumers' assessment is influenced by price besides the product high-quality and retailer attractiveness. The customers are attracted by the price perception whether it a higher price or lower one but with high quality. They also perceive that the high price is related to their perception of the high-quality 
product they buy with it. How they can be attracted is by the advertising program done by the companies. Therefore, pricing is also a good strategy so that the companies should increase the customers' perception towards the products of high quality with a high price (Wu et al., 2014).

The company can determine the price based on their high-quality products for higher profits. Therefore, the customers who pay for the company's products or services also think about the price for good quality. From the price, the company can also determine its sustainability. Harsono (2013) stated that hat price is one of the important factors in the marketing mix. There are still other three elements in the marketing mix such as products, placement, and promotion.

\section{Brand Image}

The customers very often view brand image to decide to buy or purchase the products or services. Duta and Imade (2018) stated that consumers more often buy products with well-known brands. They feel more comfortable with the brand they have already known. The famous brands are more reliable, always available, and easy to find, and have quality. The more recognized the brands, the more often chosen by consumers over unknown brands. Research by Oladepo and Abimbola (2015) showed a significant effect of brand image on the customers' decision to purchase. Brand image is important for the company to attract customers to decide to buy the company's products or services.

In connection, Dib and Alnazer (2013) defined brand image as the customers' mind for the association process towards a certain product's brand. This process is dealt with associating the customers' memory about the specification of the brand. It also deals with the traits, strengths, as well as the brand's weaknesses. In connection with this brand image, Setya and Soni (2018) suggest that the companies should provide their customers with some information related to the company's products or services. By doing so, they can help their customers increase the decision to buy the product or service. By giving more information about the product image, their customers can distinguish their own brand from other products' brand. This is created by the company using the brand image.

Indicators that can be used to measure performance refers to research by Widyastuti and Said (2017), Muawanah (2014), and Yanti and Sukotjo (2016). These are brand recognition, well-known the brand, memorable brand, and corporate image.

\section{Brand Association}

Brand association is an individual or person's mind with his impression associated with his memory towards a certain brand. Several interconnected brand processes of association create a brand image. When there are more associations, the stronger the image of the product or service is (Durianto, 2004). In relation to this brand association, Kotler and Keller (2007) argued that brand association is the person's impressions that arise in his mind with his memory towards a certain brand. This is caused by many things the individual or a person has in relation to a certain product or service. This happens during the communication process, such as the company's strategy in their marketing. The company communicates its product brand through a marketing strategy. Therefore, communication in a marketing strategy can make the customers experience the product or service they buy. They experience when they buy the products or services-thus consuming the brand as well.

Yanti and Sukotjo (2016) stated brand association is always associated with the products or services the customers buy as the lifestyles. It shows their social status and social class. A brand association can also indicate the customers' professional roles. For example, the customers feel that they can apply it by using the products or services they have purchased. Then they can be considered as the types of people with the high brand. This is their association with the brand. It can also represent the store, selling the products with certain customers associated with their social class.

In this case, Hermawan (2012) described that brand association as the person's memory towards a certain brand, which does not only occur in the customers' life but also in a certain degree of its power any time. It can be stronger when it is based on lots of customers' experiences of communication. This communication is often done during the marketing process. It is also similar to the statement by Aaker (2013). It is stated that the process of association of the brand is very much correlated with the company and the product or service brand. 
The experience above can be very long, becoming a long-lasting asset possessed by the company. The customers' experience reflects the company's strategic position of the company's product or services. For that reason, the brand association is always both directly and indirectly connected with the customer's memory of the brand. Finally, Aaker (1997) also argued that the factor of brand association concerns anything associated with the person's memory towards a certain brand. Indicators that can measure performance refer to research by Muawanah (2014) and Yanti and Sukotjo (2016) as follows: Product Attributes, Functional Benefits, and Attitude.

\section{Purchase Decision}

The purchase decision is the final goal of any effort the company wants its customers to make. The customers - finally - have to make their own decision to buy such a product. Their final decision, in this case, is the result of their consideration of that product they want to buy. Their process of considering purchasing a product has several steps. Kotler and Keller (2009) explained in more details. They described that making the customers purchase is a well-established strategy in marketing and consumer literature behavior. The theory explains that when customers make decisions to purchase, they always involve a certain process. This process includes five stages: problem recognition, information search, evaluation of product options, purchase decisions, and post-purchase support.

First of all, the customers have recognized their problem or need. Then, they search for any information related to their problem or need. In this step, they search for information about the product and price. The second is searching for information as to their hard effort until they find it completely. The next stage is to decide to purchase. In this stage, they try to evaluate the products and the options (evaluation process). They get involved in examining and comparing the product attributes such as price, brand, quality, and the like.

More importantly, it is argued by Dinawan (2010) that the concept of a purchase decision is concerned with the customers' understanding of their wants or needs for a certain product. Before deciding to buy a certain product, the customers are evaluating by looking at the existing sources of information about the product or service they want to purchase, by identifying different alternatives, and finally purchase the product. Meyliana (2012) argued that the customer's purchasing decision is also the process initially to identify all possible alternatives for solving their problem (purchasing the product) and then evaluating their choice systematically and objectively, also thinking about the benefits of different products.

Based on the arguments referred to by the previous theories and studies, this study's framework can be drawn as in Figure 1. Product performance, price perception, brand image, and brand association are assumed to affect the purchasing decision by the customers toward the products of Honda CBR-150cc motorbikes.

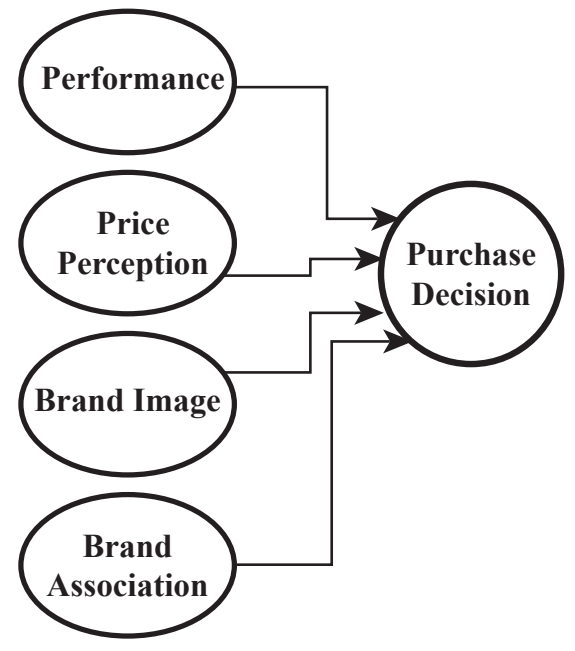

Figure 1. Framework of the Study 


\subsection{Methods}

This is quantitative research, in which the data were collected using questionnaires distributed to the respondents who are CBR Honda motorcycle customers, chosen based on the stipulated criteria. The data were analyzed using multiple linear regression analysis and t-test with SPSS 16.0, using descriptive analysis, classic assumption analysis, validity, and reliability test. To make sure the regression model measures the correlation between independent variables, the data were normally distributed, valid, and reliable.

This study took the users of All New CBR 150R in Surabaya. According to Bungin (2013), the sample should be drawn from the population (Juliansyah Noor, 2016) and generalized as the entire population. The formula referred to Sagala et al. (2014) and the number of respondents was at least more than 82 respondents. The total number of respondents used was 113 , considering that it should consist of 30 respondents for small samples, and 82 for large samples. This study should use at least 82 but the researchers got the sample, as collected and validated, up to finally 113 respondents. It is, therefore, complied with the formula as stipulated, it should at least consist of 82 respondents.

The criteria are the All-New CBR 105R who have just bought in a new condition for a period of 3 to 6 months, with their own intention to purchase, and bought the CBR 150R with their own money. The sample was taken using the non-probability sampling method/non-random sampling (Ruslan, 2010). Data were analyzed using the mean and regression analysis.

\subsection{Results and Discussion}

\section{Independent variables towards the decision to purchase}

Considering purchase decisions by the customers, it can be seen in Table 1. The respondents' responses to the average purchase decision variable strongly agree with the statement items in the questionnaire: they recognize their problem, search for information, evaluate the alternative, and then finally decided to purchase.

Table 1. Descriptive Statistic Output Results

\begin{tabular}{cccccccc}
\hline $\begin{array}{c}\text { Variable's } \\
\text { Indicator }\end{array}$ & $\mathbf{N}$ & Mean & Description & $\begin{array}{c}\text { Variable's } \\
\text { Indicator }\end{array}$ & $\mathbf{N}$ & Mean & Description \\
\hline PD 1 & 113 & 4.53 & Strongly Agree & PP 3 & 113 & 3.96 & Agree \\
\hline PD 2 & 113 & 4.54 & Strongly agree & Mean(PP) & 113 & 3.52 & Agree \\
\hline PD 3 & 113 & 4.45 & Strongly Agree & BI 1 & 113 & 4.51 & Strongly Agree \\
\hline PD 4 & 113 & 4.78 & Strongly Agree & BI 2 & 113 & 4.47 & Strongly Agree \\
\hline Mean (PD) & 113 & 4.57 & Very Agree & BI 3 & 113 & 4.58 & Strongly Agree \\
\hline P 1 & 113 & 3.93 & Agree & BI4 & 113 & 4.6 & Strongly Agree \\
\hline P 2 & 113 & 3.9 & Agree & Mean (BI) & 113 & 4.54 & Strongly Agree \\
\hline P 3 & 113 & 2.89 & Agree & BA 1 & 113 & 4.54 & Strongly Agree \\
\hline Mean (P) & 113 & 3.59 & Agree & BA 2 & 113 & 4.44 & Strongly Agree \\
\hline PP 1 & 113 & 3.8 & Agree & BA 3 & 113 & 4.5 & Strongly Agree \\
\hline PP 2 & 113 & 2.81 & Agree & Mean (BA) & 113 & 4.49 & Strongly Agree \\
\hline
\end{tabular}

In Table 1, the indicator that gets the highest value is PD4 with a mean of 4.78 or included in the interval class $4.3<x \leq 5$, while PD3 is the lowest indicator with a mean value of 4.45 or included in the interval class $4.3<x \leq 5$. It shows that respondents strongly agree with the statement of the purchase decision of respondents to buy a Honda CBR 150R.

Performance. When referring to performance, as in Table 1, the respondents' responses to the average Performance $(P)$ variable agree with the statement items on the questionnaire. In Table 1 , it can also be seen that the indicator that gets the highest value is $P 1$ with a mean of 3.93 or is included in the interval class of $3.4<x \leq 4.2$, while P 3 is the lowest indicator with a mean value of 2.89 or included in the class interval $2.6<x \leq 3.4$. Overall respondents' responses to the variable 
Performance (P) from P1 to P3 showed the results they agree with the value of means 3.59 included in the class interval $3.4<x \leq 4.2$, showing that overall the respondent expressed strongly agree with the statement related to CBR 150R performance for the decision to purchase. Thus, the Honda CBR$150 R$ has good quality, durable, and powerful.

The results of this study contradict the research conducted by Ashaduzzaman et al. (2018) on the customers in Bangladesh. It was found that performance has a significant positive effect on purchasing decisions. In this present study, performance did not significantly influence purchasing decisions because the respondents did not attach an important factor in motor performance when deciding to buy a Honda CBR 150R. This is indicated by the result of the value (b) in X1 of the multiple linear regression equation, which shows that, even though the performance sector assessment is declining, the decision to buy a Honda CBR 150R will continue to increase.

Price perception. The respondents' responses to the variable price perception (PP), on average, agree with the statement items in the questionnaire. They agree that the value of money is balanced with the benefits they get from Honda CBR 150R. The price is competitive and parallel with the quality. In Table 1, it can also be seen that the indicator that gets the highest value is PP 3 with a mean of 3.96 or included in the interval class of $3.4<x \leq 4.2$, while PP 2 is the lowest indicator with a mean value of 2.81 or included in the interval class $2.6<x \leq 3.4$. On average, respondent's response to the price perception variable from PP1 to PP3 shows the results agree with mean value of 3.52 , which belongs to the class interval $3.4<x \leq 4.2$. This shows that, on average, the respondent agreed with the statement related to price perception of respondents about the price listed Honda to have a CBR 150R.

This study contradicts the research conducted by Widyastuti and Said (2017) on Sports Shoes Product through brand image, product design, and price perception. In terms of price perception, they found that price perception has a significant positive effect on purchasing decisions. However, in this present study, price perception did not significantly influence purchasing decisions because the respondents do not weigh prices too much in deciding to buy a Honda CBR 150R. According to oto.com, CBR 150R itself has a relatively expensive price compared to its competitors. This is also supported by the results of the value (b) on X2 of the multiple linear regression equation, which shows that although the perception in the sector of price perception decreases, the decision to buy Honda CBR 150R will continue to increase.

Brand image. As in Table 1, the respondents' responses to the brand Image, on average, strongly agree that the Honda CBR 150R brand is easily recognized, known, and remembered. They said the Honda has a really good brand image. The attributes get the highest value that is BI4, with a mean of 4.60 or included in the interval class $4.3<x \leq 5$, while BI2 is the lowest indicator with a mean value of 4.47 or included in the interval class $4.3<x \leq 5$.

This study also contradicts the study on perception and research conducted by Muawanah (2014) and Yanti and Sukotjo (2016) entitled the effect of brand awareness, brand association, and brand image on Aqua purchase decision. Both studies found that brand image has a significant positive influence on purchasing decisions. In this present study, brand image has no significant effect on the purchase decision of the Honda CBR 150R because the respondents did not consider the brand image of the Honda CBR 150R and the companies that produce it. The brand image still has a positive influence on purchasing decisions because the value (b) on X3 has a positive value of 0.112 .

Brand association. The respondents' responses to the Brand Association variables, on average, strongly agree with the statement items in the questionnaire: the attribute reflects the product, has functional benefit, and has a reputation for Honda CBR 150R. The attribute that gets the highest value is BA1 with a mean of 4.54 or included in the interval class $4.3<x \leq 5$, while BA2 is the lowest indicator with a mean value of 4.44 or included in the interval class $4.3<x \leq 5$. These data indicate that respondents strongly agree with the statement of the brand association owned by Honda CBR 150R.

For brand association, the results of this study are in line with a study conducted by Muawanah (2014) and Yanti and Sukotjo (2016) entitled the effect of brand awareness, brand association, and brand image on Aqua purchase decision. They also found that brand association has a significant and positive influence on purchasing decisions. The customers will always associate the high-quality product with their value when buying it or the products they possess. This brand association can significantly affect customers' purchasing decisions. Therefore, the brand association is an influential factor for increasing the customers' purchasing decisions. 


\section{Classic Assumption Analysis}

\section{Multicollinearity test}

This test aims to test whether the regression model finds a correlation between independent variables. A good regression model should not occur in a correlation between independent variables. If the variables are correlated, then this variable is not orthogonal. Orthogonal variables are independent variables whose correlation value between independent variables is zero. Multicollinearity can also be seen from VIF. If VIF $<10$, then the level of Collinearity can be tolerated. The result of the Multicollinearity Test can be seen in Table 2 .

Table 2. The Result of Multicollinearity Test

\begin{tabular}{ccccc}
\hline No. & Variables & Tolerance Value & VIF Value & Description \\
\hline 1 & Performance & 0.895 & 1.118 & No Multicollinearity \\
2 & Price perception & 0.895 & 1.119 & No Multicollinearity \\
3 & Brand image & 0.888 & 1.126 & No Multicollinearity \\
4 & Rand association & 0.873 & 1.146 & No Multicollinearity \\
\hline
\end{tabular}

Based on Table 2, the VIF values of performance, price perception, brand image, and brand association variables are less than 10. It means there is no correlation between independent variables on regression models.

\section{Normality test}

This test aims to test whether, in the regression model, confounding or residual variables have a normal distribution. For example, if it is known that the t-test and the F-test assume that the residuals follow the normal distribution. If the assumption is violated, then the statistical test becomes invalid for the small sample size. Another statistical test that can be used to test residual normality is the non-parametric statistical test. Kolmogorov-Smirnov (K-S). K-S test is done by making a hypothesis:

H0: Residual data are normally distributed

HA: Residual data are not normally distributed

If the significant value $>0.05, \mathrm{H} 0$ is accepted, which can be interpreted as residual data normally distributed (Ghozali, 2013).

Table 3. The Result of Normality Test

\begin{tabular}{lll}
\hline \multicolumn{2}{l}{ One-Sample Kolmogorov-Smirnov Test } & \\
\hline $\mathrm{N}$ & & Unstandardized Residual \\
\hline Normal Parameters & \\
& Mean & 113 \\
\hline Most Extreme Differences & Std. Deviation & 0.0000000 \\
& Absolute & 0.119 \\
& Positive & 0.051 \\
& Negative & -0.119 \\
\hline Kolmogorov-Smirnov & & 1.260 \\
Asymp. Sig. (2-tailed) & & 0.084 \\
\hline
\end{tabular}

Based on Table 3, the significant value is 0.084 . It means that $\mathrm{HO}$ is accepted, and residual data are normally distributed because the significant value $>0.05$

\section{Autocorrelation Test}

This test is used to test whether the linear regression model correlates with the error of the intruder in period $t$ and the error of the previous period intruder. A good linear regression model is if autocorrelation does not occur. Ways that can be used to detect the presence of autocorrelation symptoms include: 
Durbin Watson Test (DW Test)

$\mathrm{HO}: \mathrm{dL}<\mathrm{d}<4$-dU (no autocorrelation)

$\mathrm{H} 1: \mathrm{d}>4-\mathrm{dL}$ (there is autocorrelation)

Table 4. The Result of Autocorrelation Test

\begin{tabular}{cc}
\hline Std. Error of the Estimate & Durbin-Watson \\
\hline 1.681 & 1.528 \\
\hline
\end{tabular}

Based on Table 4, the score of Durbin Watson (D) is 1.528. According to Durbin Watson's table $(a=5 \%)$ with 113 samples and three independent variables, the value of $d L=1.5255$ and the value of $\mathrm{dU}=1.8676$. so the value of $\mathrm{D}$ is located at $\mathrm{dL}<\mathrm{d}<4-\mathrm{dU}$ or $1.5255<1.5258<1.8676$. the conclusion is there is no autocorrelation in the variables.

\section{Validity and Reliability Test}

This test aims to examine whether the item statement in questioner is valid and reliable or not. The statement in the questioner is valid if the Sig $\leq \alpha$. The criteria of the research instrument are valid if Cronbach's alpha > 0.70 .

Table 5. Results of Validity and reliability Tests

\begin{tabular}{cccc}
\hline $\begin{array}{c}\text { Variables and } \\
\text { Cronbach' Alpha }\end{array}$ & Statements & Sig & Descriptions \\
\hline \multirow{3}{*}{ P (0.778) } & P1 & 0.000 & Valid and Reliable \\
& P2 & 0.000 & Valid and Reliable \\
& P3 & 0.000 & Valid and Reliable \\
\hline & PP1 & 0.000 & Valid and Reliable \\
PP (0.857) & PP2 & 0.000 & Valid and Reliable \\
& PP3 & 0.000 & Valid and Reliable \\
\hline & BI1 & 0.000 & Valid and Reliable \\
BI (0.897) & BI2 & 0.000 & Valid and Reliable \\
& BI3 & 0.000 & Valid and Reliable \\
& BI4 & 0.000 & Valid and Reliable \\
\hline & BA1 & 0.000 & Valid and Reliable \\
BA (0.895) & BA 2 & 0.000 & Valid and Reliable \\
& BA3 & 0.000 & Valid and Reliable \\
\hline & PD1 & 0.000 & Valid and Reliable \\
PD (0.888) & PD2 & 0.000 & Valid and Reliable \\
& PD3 & 0.000 & Valid and Reliable \\
& PD4 & 0.000 & Valid and Reliable \\
\hline
\end{tabular}

Based on Table 5, the statement in the items in the questioner is valid and reliable because the significance value is $\leq \alpha$ and the Cronbach's alpha value is $>0.70$

\section{Statistical Analysis}

This study uses multiple linear regressions and t-test to determine the effect of performance, price perception, brand image, and brand associations on purchasing decisions. In multiple linear regression analysis and t-test is using SPSS 16.0.

\section{Multiple Regression Analysis}

Constanta $(a)=10.197$ shows that if the independent variables (performance, price perception, brand image, brand association) on purchase decision Honda CBR 150R in Surabaya $=0$, the Purchase Decision Honda CBR 150R in Surabaya is 10.197. The regression coefficient of performance $(X 1)=$ -0.164 shows a negative correlation between performance and purchase decision. It means that purchasing decisions are increasing even though the performance is decreasing. The regression coefficient of price perception $(X 2)=-0.012$ shows a negative correlation between price perception 
and purchase decision. It means that purchasing decisions are increasing even though the price perception is decreasing.

The regression coefficient of brand image $(X 3)$ is 0.112 , showing a positive correlation between brand image and purchase decision. It means that purchasing decisions are increasing if the brand image is also increased. The regression coefficient of brand association $(X 4)=0.590$ shows a positive correlation between the brand association and purchase decision. It means that purchasing decisions are increasing if the brand association is also increased. Error $(e)=2.214$ shows that if the error value increases by the unit, it will increase in other variables outside the independent variable in this study by 4.909 .

Table 6. The Results of Multiple Linear Regression Tests

\begin{tabular}{cc}
\hline Variables & B Value \\
\hline Performance & -0.164 \\
Price Perception & -0.012 \\
Brand Image & 0.112 \\
Brand Association & 0.590 \\
A & 10.197 \\
E & 2.214 \\
\hline
\end{tabular}

\section{2. t-test Results}

The results of data analysis using SPSS 16.0 in Table 7 shows the t-test of probability significance. If the significance value $<0.05$, then $\mathrm{H} 0$ is rejected, and $\mathrm{H} 1$ is accepted. The significance value of performance, price perception, and brand image are $0.111,0.894$, and 0.243 , which is greater than 0.05 . It shows that $\mathrm{H} 0$ is accepted and $\mathrm{H} 1$ is rejected. Therefore, performance, price perception, and brand image have no significant effect on purchasing decisions. On the other hand, the brand association has a significance value of 0,000 . This value is smaller than 0.05 . This means that brand associations have a significant effect on purchasing decisions.

Table 7. The Results of T-Test

\begin{tabular}{clc}
\hline No & Variables & Sig. \\
\hline 1 & Performance & 0.111 \\
2 & Price Perception & 0.894 \\
3 & Brand Image & 0.243 \\
4 & Brand Association & 0.000 \\
\hline
\end{tabular}

\subsection{Conclusion}

The customers who buy Honda CBR 150R do not consider the aspects of performance and price perception. They decide to buy this motorbike because of the brand image and brand association. They think that by having Honda CBR 150R, they think that they have the value of the motorbike they bought. In addition, they feel that they have high value because of possessing Honda CBR 150R.

It can be implied that to increase the users of Honda CBR 150 and other next future products of the same trademark, it is important for the company, especially the producers, to pay attention to the brand. The brand of the motorcycle is always associated with the users' decision to purchase. Maintaining the brand of the product is required.

For that reason, based on the findings, the researchers have some recommendations for future research. It would be better to assess a product, especially the $150 \mathrm{cc}$ motorsport; there are many differences in consumer behavior towards one product and another. Therefore, further research is expected to examine different objects with the same independent variables and locations.

This study suggests that the company of Honda should pay attention to the brand image and brand association to increase the customers' decision to purchase Honda motorbikes. Price perception has no significant positive effect on purchasing decisions because consumers are also 
not too much concerned with the price listed by Honda to buy a CBR $150 R$ when deciding to buy a Honda CBR 150R. Brand image and brand association are the important factors for Honda Motorbike Company to increase the customer's decision to purchase. For further study, when considering the region, the respondents were taken from Surabaya, a city in East Java-further study may include more variables that were not examined in this study.

\section{REFERENCES}

Aaker, D. A. (1997). Should you take your brand to where the action is? Harvard business review, 75(5), 135-144.

Aaker, D. A. (2013). Manajemen pemasaran strategis. Edisi kedelapan. Salemba Empat. Jakarta.

Aghdaie, S. F. A., \& Yousefi, E. (2011). The comparative analysis of affecting factors on purchasing domestic and imported cars in Iran market-using AHP technique. International Journal of Marketing Studies, 3(2), 142.

Ashaduzzaman, M., Hoque, I., \& Mahbub, F. (2018). Factors influencing bike purchase decisions: A study of consumers in Bangladesh. South Asian Journal of Management, 25(1).

Bungin, B. (2013). Metodologi penelitian sosial dan ekonomi. Jakarta: kencana prenada media group.

Dinawan, M. R. (2010). Analisis faktor-faktor yang mempengaruhi keputusan pembelian (studi kasus pada konsumen yamaha mio pt harpindo jaya semarang) (Doctoral dissertation, Universitas Diponegoro).

Dib, H., \& Alnazer, M. (2013). The impact of sales promotion on perceived transaction value and purchase intentions: the moderating role of promotional benefit level. International Journal of Economy, Management and Social Sciences, 2(9), 731-736.

Durianto, D. (2004). Brand equity ten strategi memimpin pasar. Gramedia Pustaka Utama.

Duta, P. I. A., \& Imade, W. (2018). Antecedent brand equity and consequences on repurchase intention. Russian Journal of Agricultural and Socio-Economic Sciences, 82(10).

Fattah, M. C. (2016). Pengaruh citra merek dan desain produk terhadap keputusan pembelian all new honda Cbr $150 \mathrm{R}$ (Studi pada dealer honda cemara agung motor magetan). Jurnal Pendidikan Tata Niaga (JPTN), 4(1).

Fink, R. C., James, W. L., \& Hatten, K. J. (2011). Pricing, purchasing, and product performance factors associated with the relational exchanges of different sized customers. Journal of Business \& Industrial Marketing. 34-44.

Ghozali, I., \& Ratmono, D. (2013). Analisis multivariat dan ekonometrika: Teori, konsep, dan aplikasi dengan EVIEWS 8. Semarang: Badan Penerbit Universitas Diponegoro.

Hermawan, A. (2012). Komunikasi pemasaran.

Harsono, S. (2013). Pengaruh harga, nilai manfaat, dan kualitas terhadap kepuasan pelanggan handphone blackberry di Surabaya. Journal of Business and Banking, 3(2), 135-150., 3(2), 135150.

Juliansyah Noor, S. E. (2016). Metodologi Penelitian: Skripsi, Tesis, Disertasi \& Karya Ilmiah. Prenada Media.

Kotler, P., \& Keller, K. L. (2007). Manajemen pemasaran, edisi kedua belas, jilid II, PT. Macaran Jaya Cemerlang, Jakarta.

Kotler, P., \& Keller, K. L. (2009). Dirección de marketing. Pearson educación.

Kotler, P., \& Pfoertsch, W. (2010). Managing Ingredient Brands and Measuring the Performance of InBrands. In Ingredient Branding (pp. 277-330). Springer, Berlin, Heidelberg.

Meyliana, M. (2012). Pengaruh komunitas virtual dalam keputusan pembelian. Jurnal Fakultas Hukum UII.

Muawanah, U. (2014). Corporate governance dan kepemilikan keluarga. Jurnal Akuntansi Multiparadigma, 5(2), 299-313.

Oladepo, O. I., \& Abimbola, O. S. (2015). The influence of brand image and promotional mix on consumer buying decision-a study of beverage consumers in Lagos State, Nigeria. British journal of marketing studies, 3(4), 97-109.

Pratiwi, G. I. (2015). Perilaku konsumtif dan bentuk gaya hidup (Studi Fenomenologi pada Anggota Komunitas Motor Bike of Kawasaki Riders Club (BKRC) Chapter Malang). Jurnal Mahasiswa Sosiologi, 1(5). 
Puspitasari, I. (2013). Studi komparasi performa motor yamaha jupiter MX 2010 berbahan bakar biopremium dengan pertamax. Jurnal Teknik Mesin, 1(2), 211-220.

Ruslan, R. (2010). Metode penelitian public relation \& komunikasi. Jakarta (ID): Rajawali Pers.

Sagala, C., Destriani, M., Putri, U. K., \& Kumar, S. (2014). Influence of promotional mix and price on customer buying decision toward fast food sector: a survey on university students in Jabodetabek (Jakarta, Bogor, Depok, Tangerang, Bekasi) Indonesia. International Journal of Scientific and Research Publications, 4(1), 1-7.

Setya, B. I., \& Soni, H. (2018). The effect of brand image and product on customer satisfaction and willingness to pay at coffee bean Surabaya. Russian Journal of Agricultural and Socio-Economic Sciences, 73(1).

Widyastuti, S., \& Said, M. (2017). Consumer consideration in the purchase decision of SPECS sports shoes product through the brand image, product design, and price perception. International Journal of Supply Chain Management, 6(4), 199-207.

Wu, Y. F., Wu, C. S., Lee, C. J., \& Tsai, L. F. (2014). The relationship between packages redesign and purchase intention. International Journal of Organizational Innovation (Online), 6(3), 50.

Yanti, M. O. Z., \& Sukotjo, H. (2016). Pengaruh kesadaran merek, asosiasi merek, dan brand image terhadap keputusan pembelian Aqua. Jurnal Ilmu Dan Riset Manajemen (JIRM), 5(5).

\section{Correspondence:}

PONTA DEWA SAKTIAWAN

pontadewasaktiawan@gmail.com

https://orcid.org/0000-0003-1586-5456

SONI HARSONO

soni@perbanas.ac.id

https://orcid.org/0000-0002-3871-6034 